\title{
Curcuma Oil: Reduces Early Accumulation of Oxidative Product and is Anti-apoptogenic in Transient Focal Ischemia in Rat Brain
}

Priyanka Rathore Preeti Dohare $\cdot$ Saurabh Varma $\cdot$ Aparajita Ray

Uma Sharma $\cdot$ N. R. Jagannathan · Madhur Ray

Published online: 12 July 2008

(C) Springer Science+Business Media, LLC 2008

Erratum to: Neurochem Res

DOI 10.1007/s11064-007-9515-6

The family name of one of the authors-JAGANNATHAN-is misspelled in the published article. Please note the correct spelling as shown in this erratum.

The online version of the original article can be found under doi:10.1007/s11064-007-9515-6.

P. Rathore · P. Dohare · M. Ray $(\bowtie)$

Division of Pharmacology, Central Drug Research Institute,

P.O Box no 173, Chattar Manzil Palace,

Lucknow, UP 226001, India

e-mail: raymadhur@gmail.com

S. Varma

Institute of Pathology, Indian Council of Medical Research,

New Delhi, India

A. Ray · U. Sharma · N. R. Jagannathan

All India Institute of Medical Sciences, New Delhi, India 